Int. J. Electrochem. Sci., 1(2006)80-91

International Journal of

ELECTROCHEMICAL

SCIENCE

www.electrochemsci.org

\title{
Corrosion and Inhibition of 316L stainless steel in neutral medium by 2-Mercaptobenzimidazole
}

\author{
S. A. M. Refaey*, F. Taha and A. M. Abd El-Malak \\ Chemistry Department, Faculty of Science, Minia University, Minia, Egypt. \\ *E-mail: Saeed_refaey@hotmail.com
}

Received: 5 May 2006/ Accepted: 18 May 2006/Published: 27 May 2006

The electrochemical behavior of 316L stainless steel (316L SS) in $\mathrm{NaCl}$ solution by using potentiondynamic, EDX and scanning electron microscope (SEM) techniques was determined. The addition effect of 2-mercaptobenzimidazole (MBI) on the pitting corrosion of $316 \mathrm{~L} \mathrm{SS}$ in $\mathrm{NaCl}$ solutions were investigated at different temperatures $\left(25,40,50\right.$ and $\left.60{ }^{\circ} \mathrm{C}\right)$. The results indicate that the increase of MBI concentration leads to shift the pitting potential to more positive potential, i.e. pitting corrosion inhibition. The corrosion inhibition behavior of MBI argued to the adsorption of 2mercaptobenzimidazole, which can impede the aggressive anions to reach the base 316L SS surface. The protection efficiency increases with increasing MBI concentration but decreased with the increasing of the temperature.

Keywords: pitting corrosion, inhibition, 2-mercaptobenzimidazole, 316L stainless steel and thermodynamic parameters

\section{INTRODUCTION}

Pitting corrosion of $316 \mathrm{~L} \mathrm{SS}$ is of great practical interest, it can be a destructive form of corrosion in engineering structures if it causes perforation of equipment. Most equipment failures in SS used by pitting corrosion, which is caused by chloride ions $[1,2]$. However, nonaggressive anions in aqueous solutions play an important role in the passivation process. Nonaggressive anions that reduce the pitting corrosion of SS in $\mathrm{Cl}^{-}$solutions include sulfate, chromate, bicarbonate, and phosphate ions [35]. Protection mechanism thought to involve the formation of more protective passive film [6]. MBI is an organic heterocyclic inhibitor [7] and it has a several interesting properties as high thermal stability (which allows exposing the coating to high temperatures). MBI was used as inhibitor for mild steel in sulfuric acid solution [8], steel, copper and copper alloys in $\mathrm{HCl}$ [9-11], mild steel and zinc in 
phosphoric acid [12,13]. However, no work done appears on the inhibition of 316L SS by MBI in aqueous solutions of $\mathrm{NaCl}$. The aim of the present work is the investigation of the inhibition behavior of MBI and calculation of kinetic parameters such as activation energy Ea, activation entropy $\Delta S$, activation enthalpy $\Delta \mathrm{H}$ and thermodynamic parameters such as free energy of adsorption $\Delta \mathrm{G}$ and values of equilibrium constant

\section{EXPERIMENTAL PART}

\subsection{Materials}

MBI compound (Fluka) used as received. All solutions were prepared from doubly distilled water and A. R. chemicals. Freshly polished electrodes used for each run. All solutions used under purified nitrogen gas. The composition of $316 \mathrm{~L}$ SS is $0.03 \% \mathrm{C}, 2.0 \% \mathrm{Mn}, 0.1 \% \mathrm{Si}, 0.45 \% \mathrm{P}, 18 \% \mathrm{Cr}$, $14 \% \mathrm{Ni}, 0.03 \% \mathrm{~S}, 3 \% \mathrm{Mo}$ and the remainder being iron. Before use of the electrodes (as rods), its polished successively with emery papers up to grade 400, degreased with acetone and then rinsed with doubly distilled water. A Pt sheet used as counter electrode. The potential measured against $\mathrm{Ag} / \mathrm{AgCl}$ reference electrode. Experiments carried out in $\mathrm{NaCl}$ solutions in absence and in presence of different concentrations of MBI. The working electrode was prepared and treated following the procedure described previously [14].

\subsection{Methods and instruments}

For the polarization study, a standard corrosion cell with a working SS electrode of crosssection $1.0 \mathrm{~cm}^{2}$ used. The corrosion rate calculated from the polarization measurements (Tafel lines). The polarization measurements run on a computerized potentiostat (Radiometer model VoltaLab 40) and VoltaMaster 4 program. The mor4phology of SS corroded surface examined by SEM (scanning electron microscope), Jeol JSM T200. SEM and EDX (overall sample surface area) examinations of 316L SS surface potentiodynamically polarized from -700 to $2000 \mathrm{mV}$ at $20 \mathrm{mV} \mathrm{s}^{-1}$ in $0.5 \mathrm{M} \mathrm{NaCl}$ in the absence and presence of $0.001 \mathrm{M}$ MBI solutions was carried out

\section{RESULTS AND DISCUSSION}

\subsection{Influence of $\mathrm{NaCl}$ concentration}

The polarization curves for $316 \mathrm{~L} \mathrm{SS}$ in different concentrations of $\mathrm{NaCl}$ solution at scan rate 20 $\mathrm{mV} \mathrm{s}^{-1}$ in the potential range from -700 to $2000 \mathrm{mV}$ are shown in Figure 1. The scans have the same general features and characterized by the appearance of passive and transpassive regions. The passivation current ( $\mathrm{i}_{\text {pass }}$ ) decreases over extending a wide range of potential due to formation of the passive layer on SS surface. The passive layer formed on 316L SS in aqueous $\mathrm{NaCl}$ solutions consists of $\mathrm{Fe}_{2} \mathrm{O}_{3}, \mathrm{Cr}_{2} \mathrm{O}_{3}$ and $\mathrm{FeCl}[15,16]$. The current density starts to increase with increasing of the 


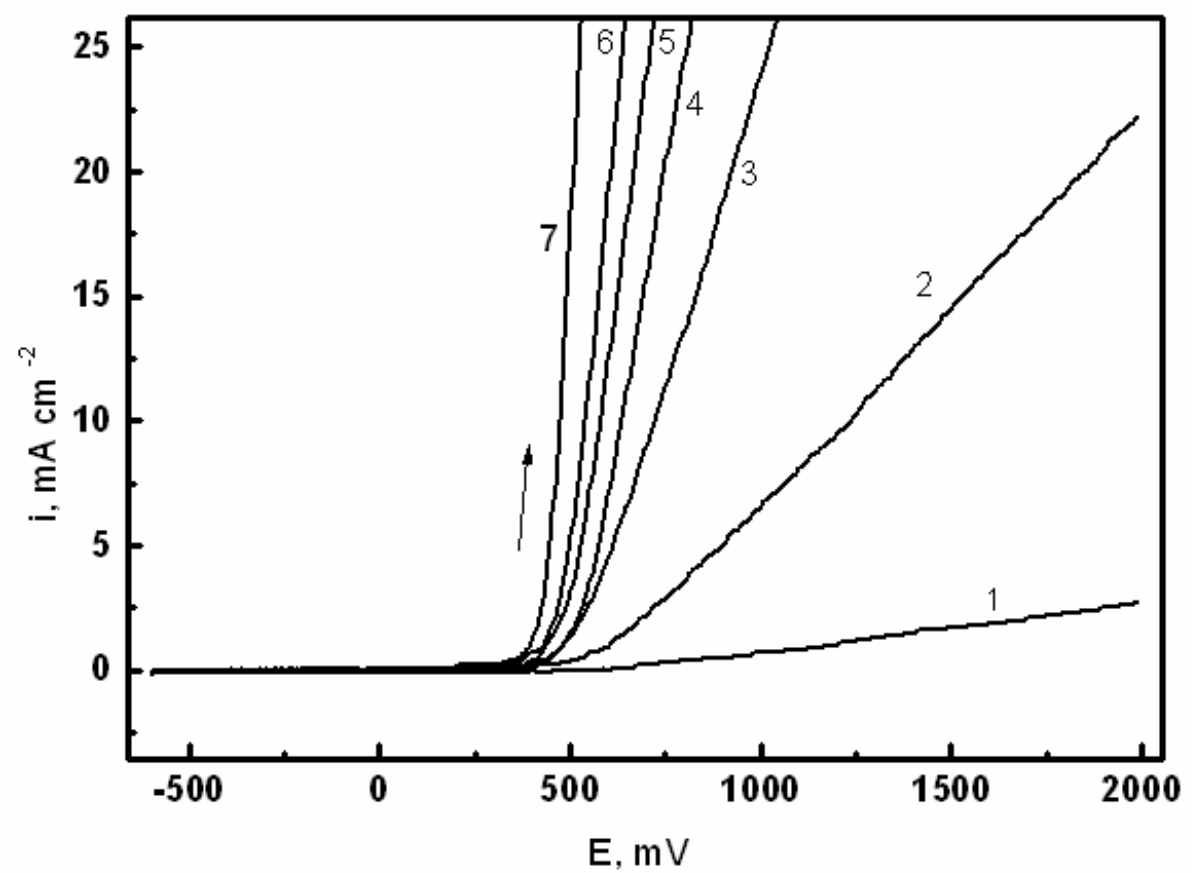

Figure 1. Anodic potentiodynamic curves for 316L SS anode in the presence of $\mathrm{NaCl}$ solutions of different concentrations: 1) 0.01, (2) 0.1 , (3) 0.3 , (4) 0.5 , (5) 0.7, , (6) 1.0 and (7) $2.0 \mathrm{M} \mathrm{NaCl}$.

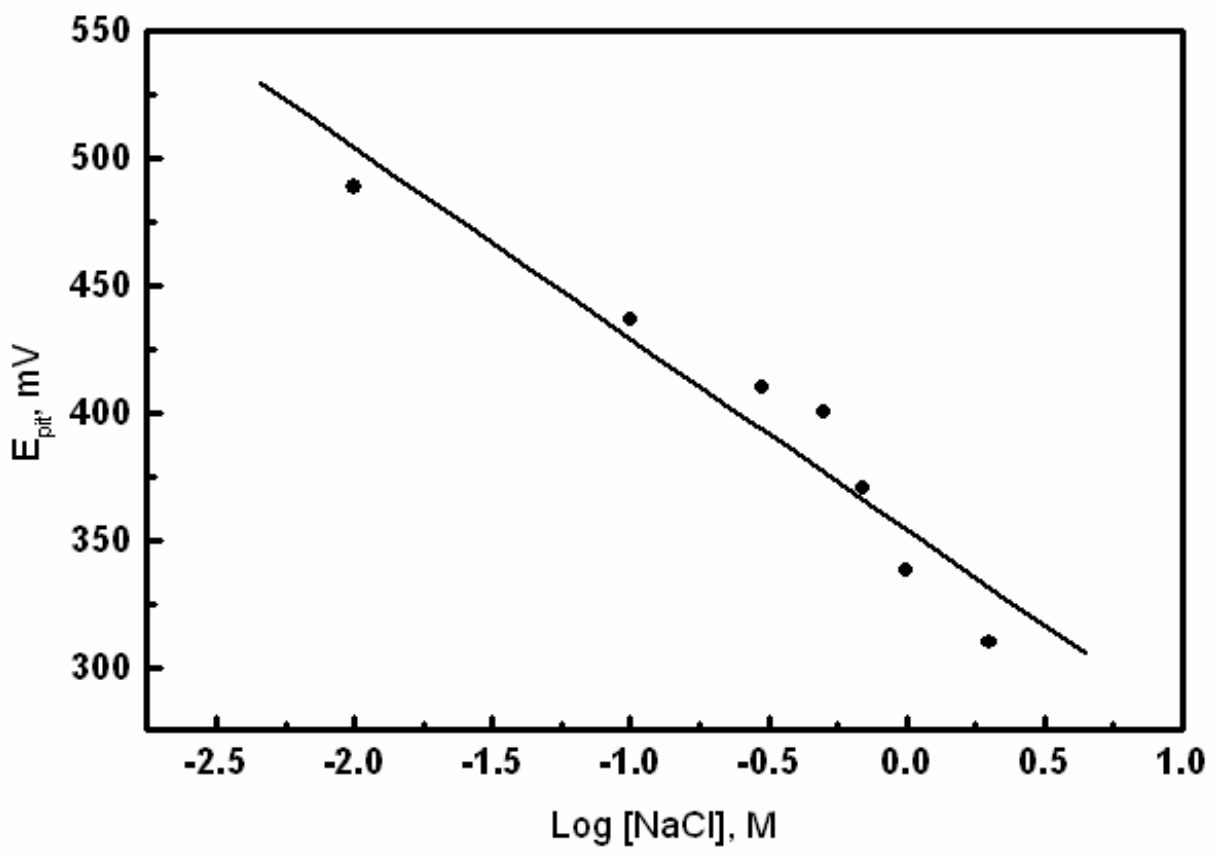

Figure 2. Pitting potential $\left(\mathrm{E}_{\mathrm{pit}}\right)$ for $316 \mathrm{~L} \mathrm{SS}$ as a function of $\mathrm{NaCl}$ concentration.

potential in the positive direction due to transpassivation process before oxygen evolution. The current rises suddenly without any sign of oxygen evolution denoting breakdown of the passive layer and nucleation of pitting corrosion. This result can explain by dissolution of adsorbed $\mathrm{FeCl}$ layer to $\mathrm{FeCl}^{+}$ 
[17]. The weak sites produced from the dissolution acted as a nucleation of pits in the 316L SS surface. Figure 2 shows the relation between $\mathrm{E}_{\text {pit }}$ and $\mathrm{NaCl}$ concentration, a straight line obtained according to the following equation:

$$
\mathrm{E}_{\text {pit }}=\mathrm{a}-\mathrm{b} \log [\mathrm{NaCl}]
$$

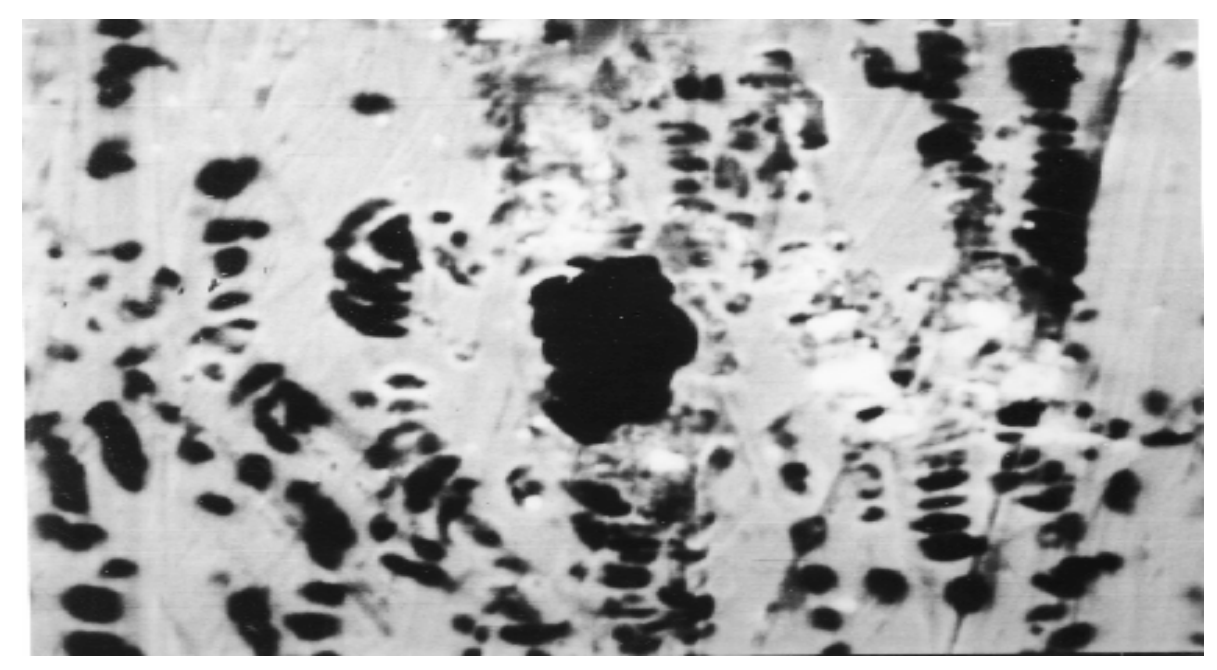

Figure 3. SEM of the surface of 316L SS anode after potentiodynamically treated in $0.5 \mathrm{M} \mathrm{NaCl}$.

Where $a$ and $b$ are constants. The value of $b$ is $+75 \mathrm{mV}$ in presence of $\mathrm{NaCl}$. This result shows that the pitting corrosion of 316L SS depends on the salt concentration. The increase of $\mathrm{NaCl}$ concentration shifts $\mathrm{E}_{\text {pit }}$ to more positive potentials i.e., increases the pitting corrosion. EDX (overall sample surface area) used to determine the composition of the passive layer formed on 316L SS surface. The results indicate that the atomic percent of different elements as the following: $65.98 \% \mathrm{Fe}, 19.57 \% \mathrm{Cr}, 2.18 \%$ $\mathrm{Mn}, 9.77 \% \mathrm{Ni}, 0.92 \% \mathrm{Si}, 0.47 \% \mathrm{Cl}$ and $1.1 \% \mathrm{Mo}$. The surface EDX analysis makes up $\mathrm{Fe}, \mathrm{Cr}, \mathrm{Cl}$ and oxygen signals. The latter can be attributing to the formation of $\mathrm{Fe}_{2} \mathrm{O}_{3}, \mathrm{Cr}_{2} \mathrm{O}_{3}$ and $\mathrm{FeCl}$ as mentioned above. SEM investigations of corroded 316L SS surface indicate that the surface was containing high density of pits (Fig. 3).

\subsection{Effect of MBI concentration}

The effect of adding different concentrations of MBI on the pitting corrosion behavior of 316L $\mathrm{SS}$ in $\mathrm{NaCl}$ solution investigated. The addition of $\mathrm{MBI}$ to $0.5 \mathrm{M} \mathrm{NaCl}$ solution increases the breakdown potential towards more positive potential (Fig. 4), i.e. inhibits pitting corrosion. Figure 5 shows the relation between $\mathrm{E}_{\text {pit }}$ and $\mathrm{MBI}$ concentration, a straight line obtained according to the following equation:

$$
\mathrm{E}_{\text {pit }}=\mathrm{a}^{\prime \prime}-\mathrm{b}^{\prime \prime} \log [\mathrm{MBI}]
$$


Symbols a" and b" are constants. The increase of MBI concentration increases the pitting potential towards the nobel value, i.e. decreases the pitting corrosion.

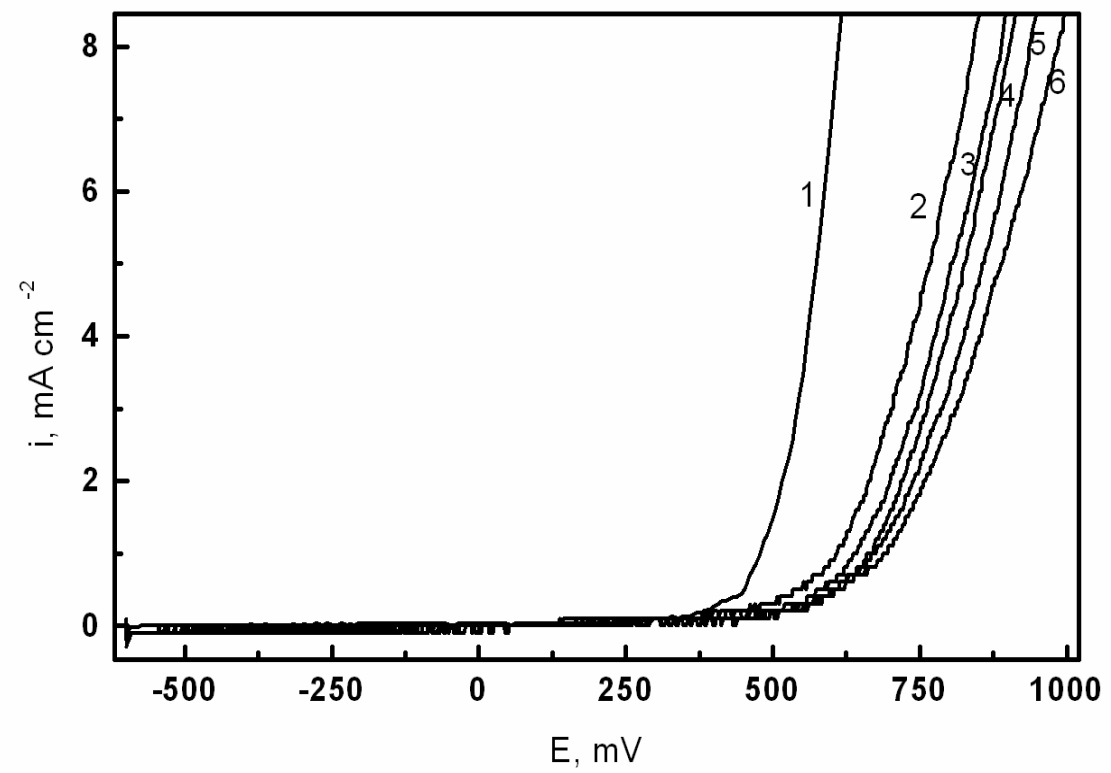

Figure 4. Anodic potentiodynamic curves for $316 \mathrm{~L} \mathrm{SS}$ anode in $0.5 \mathrm{M} \mathrm{NaCl}$ in the presence of various concentrations of MBI: (1) 0.0 , (2) $10^{-6}$, (3) $10^{-5}$, (4) $10^{-4}$, (5) $10^{-3}$ and (6) $1.5 \times 10^{-3} \mathrm{M}$.

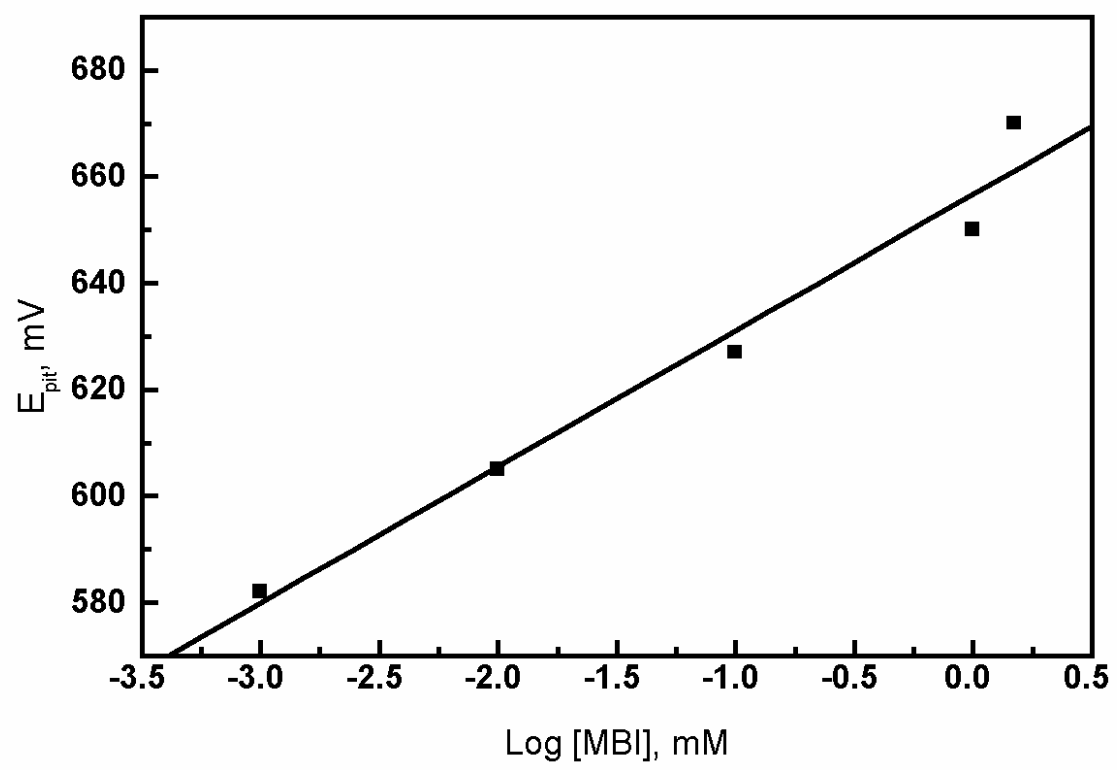

Figure 5. Pitting potential $\left(\mathrm{E}_{\text {pit }}\right.$ ) as a function of $\mathrm{MBI}$ concentration for $316 \mathrm{~L}$ SS in presence of $0.5 \mathrm{M}$ $\mathrm{NaCl}$ solution..

The $\mathrm{pk}_{\mathrm{a}}$ value for $-\mathrm{SH}$ group in MBI equals to 10.55 [18], this means that MBI has low dissociation ability, i.e. the possibility of the M-MBI complex formation is very low. One can argue the corrosion inhibition behavior to the adsorption of MBI, which can impede the aggressive anions to reach to 
the base 316L SS surface throw the pits. The polar MBI can adsorb on the surface, the ionization of MBI as following:<smiles>[S]c1nc2ccccc2[nH]1</smiles>

The adsorption of ionized MBI on positively charged surface can prevent the adsorption of $\mathrm{Cl}^{-}$ ion (which is responsible for pitting corrosion). SEM examination of $316 \mathrm{~L}$ SS surface potentiodynamically polarized from -700 to $2000 \mathrm{mV}$ at $20 \mathrm{mV} \mathrm{s}^{-1}$ in $0.5 \mathrm{M} \mathrm{NaCl}$ in the presence of $0.001 \mathrm{M}$ MBI solutions was carried out (Fig. 6). The micrograph shows no evidence of pits and formation of passive film on the stainless steel surface.

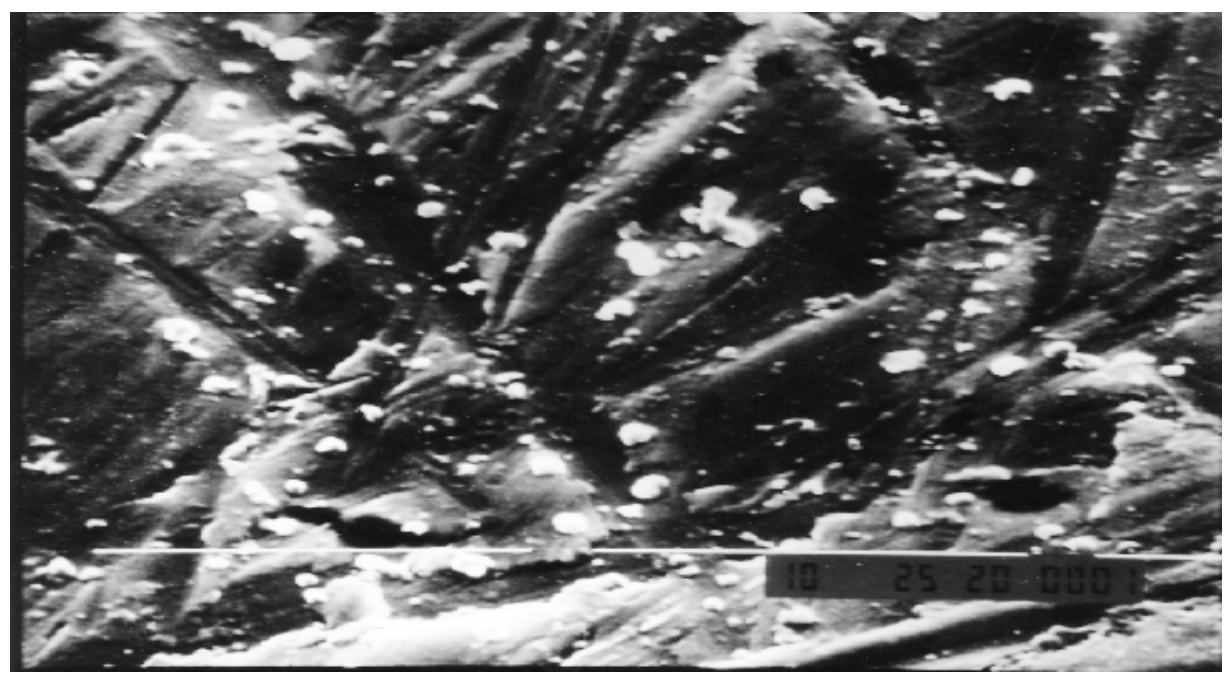

Figure 6. SEM of the 316L SS surface after potentiodynamically treated in $0.5 \mathrm{M} \mathrm{NaCl}+0.001 \mathrm{M}$ MBI solution.

Effects of MBI concentration variation on the anodic and cathodic polarization for 316L SS electrode in $0.5 \mathrm{M} \mathrm{NaCl}$ at different temperatures were determined. Figure 7 shows the change of corrosion rate $\mathrm{R}_{2}$ with $\mathrm{MBI}$ concentration. The corrosion rates can obtain by extrapolation of the anodic and cathodic Tafel lines. The corrosion rate decreases with the increasing of MBI concentration, i.e. retards the corrosion of $316 \mathrm{~L} \mathrm{SS}$ in $0.5 \mathrm{M} \mathrm{NaCl}$. The corrosion potential ( $\mathrm{E}_{\mathrm{corr}}$ ) shifted to more positive potential (Table 1) with increase MBI concentration. This result indicates that the MBI is anodic inhibitor. The increase of the temperature from 25 to $60^{\circ} \mathrm{C}$ increases the corrosion rate due to desorption of inhibitor molecules from the surface. The inhibition efficiency (IE) was also determined from polarization measurements according to the following equation [19]:

$$
\operatorname{IE}(\%)=\left[1-\left(\mathrm{R}_{1} / \mathrm{R}_{2}\right)\right] \times 100
$$


The $R_{1}$ and $R_{2}$ are the corrosion rates in the presence and absence of MBI respectively. The IE calculated from the polarization data given in Fig. 8. The results indicate that IE depends on the concentration of the inhibitor and temperature.

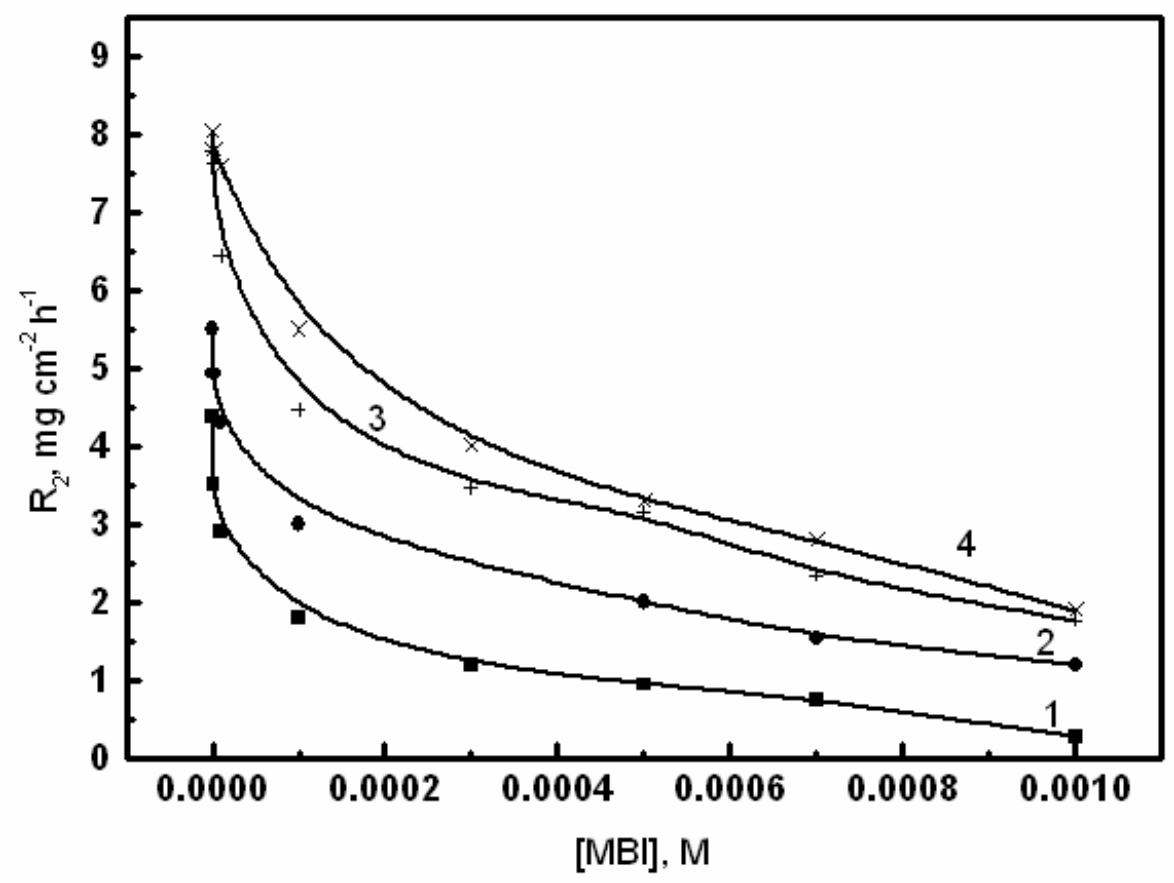

Figure 7. Variation of corrosion rate with the concentrations of MBI for the $316 \mathrm{~L} \mathrm{SS} 0.5 \mathrm{M} \mathrm{NaCl}$ at different temperatures: (1) 25, (2) 40, (3) 50 and (4) $60^{\circ} \mathrm{C}$.

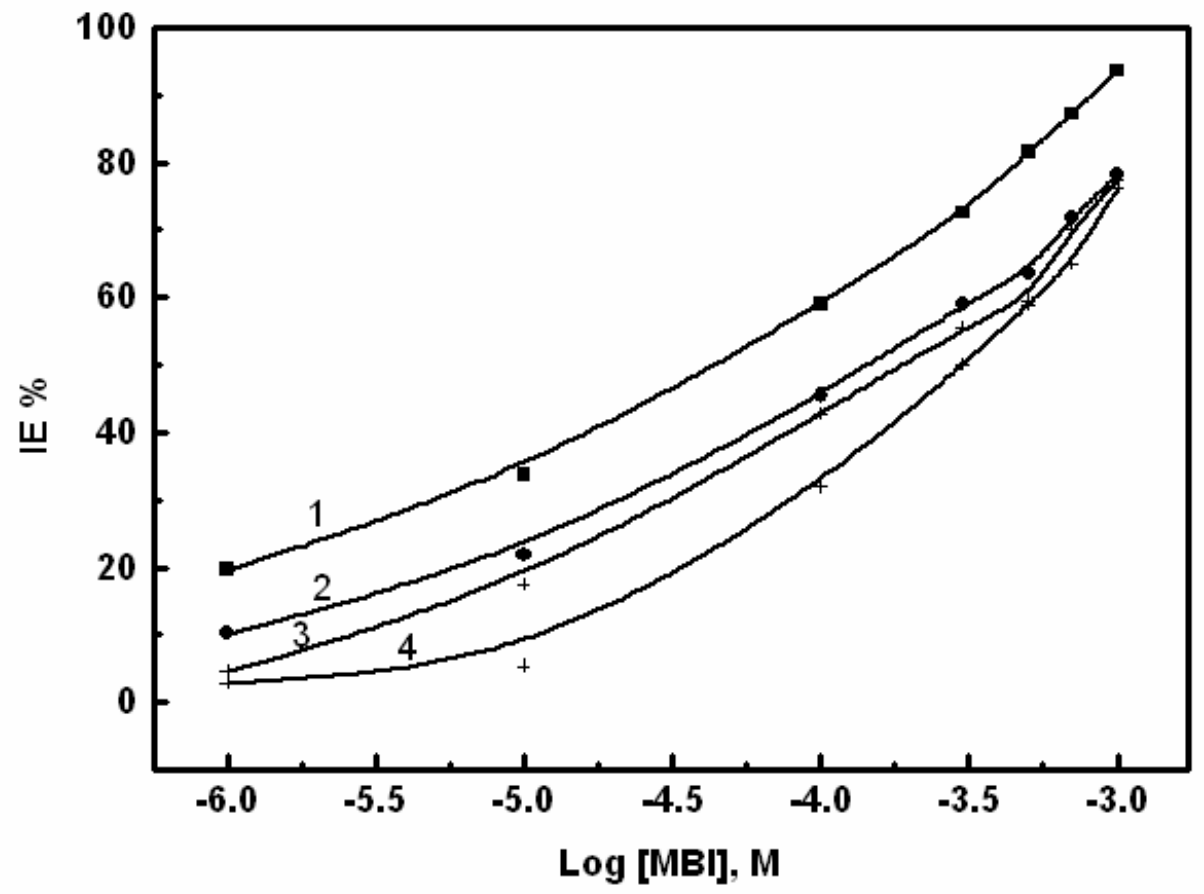

Figure 8. Variation of protection efficiency (IE\%) with the logarithmic concentration of MBI for the 316 SS in $0.5 \mathrm{M} \mathrm{NaCl}$ at different temperatures: (1) 25, (2) 40, (3) 50 and (4) $60^{\circ} \mathrm{C}$. 
Table 1. Activation parameters for the dissolution reaction of $316 \mathrm{~L} \mathrm{SS}$ in presence of MBI in $0.5 \mathrm{M}$ $\mathrm{NaCl}$ at $25^{\circ} \mathrm{C}$.

\begin{tabular}{|l|c|c|c|c|}
\hline $\begin{array}{c}\text { Conc. } \\
\left(\mathrm{x} 10^{3} \mathrm{M}\right)\end{array}$ & $\begin{array}{c}\mathrm{E}_{\mathrm{a}} \\
\left(\mathrm{kJ} \mathrm{mol}^{-1}\right)\end{array}$ & $\begin{array}{c}\Delta \mathrm{H} \\
\left(\mathrm{kJ} \mathrm{mol}^{-1}\right)\end{array}$ & $\begin{array}{c}\Delta \mathrm{S} \\
\left(\mathrm{J} \mathrm{K}^{-1} \mathrm{~mol}^{-1}\right)\end{array}$ & $\begin{array}{c}\mathrm{E}_{\text {corr }} \\
\mathrm{mV}\end{array}$ \\
\hline 0.000 & 15.46 & 13.68 & -291 & -710 \\
0.001 & 20.19 & 19.26 & -274 & -694 \\
0.010 & 23.93 & 20.57 & -271 & -672 \\
0.100 & 25.61 & 24.72 & -262 & -661 \\
0.300 & 28.08 & 26.72 & -257 & -645 \\
0.500 & 35.61 & 33.34 & -238 & -602 \\
0.700 & 37.00 & 34.75 & -236 & -550 \\
\hline
\end{tabular}

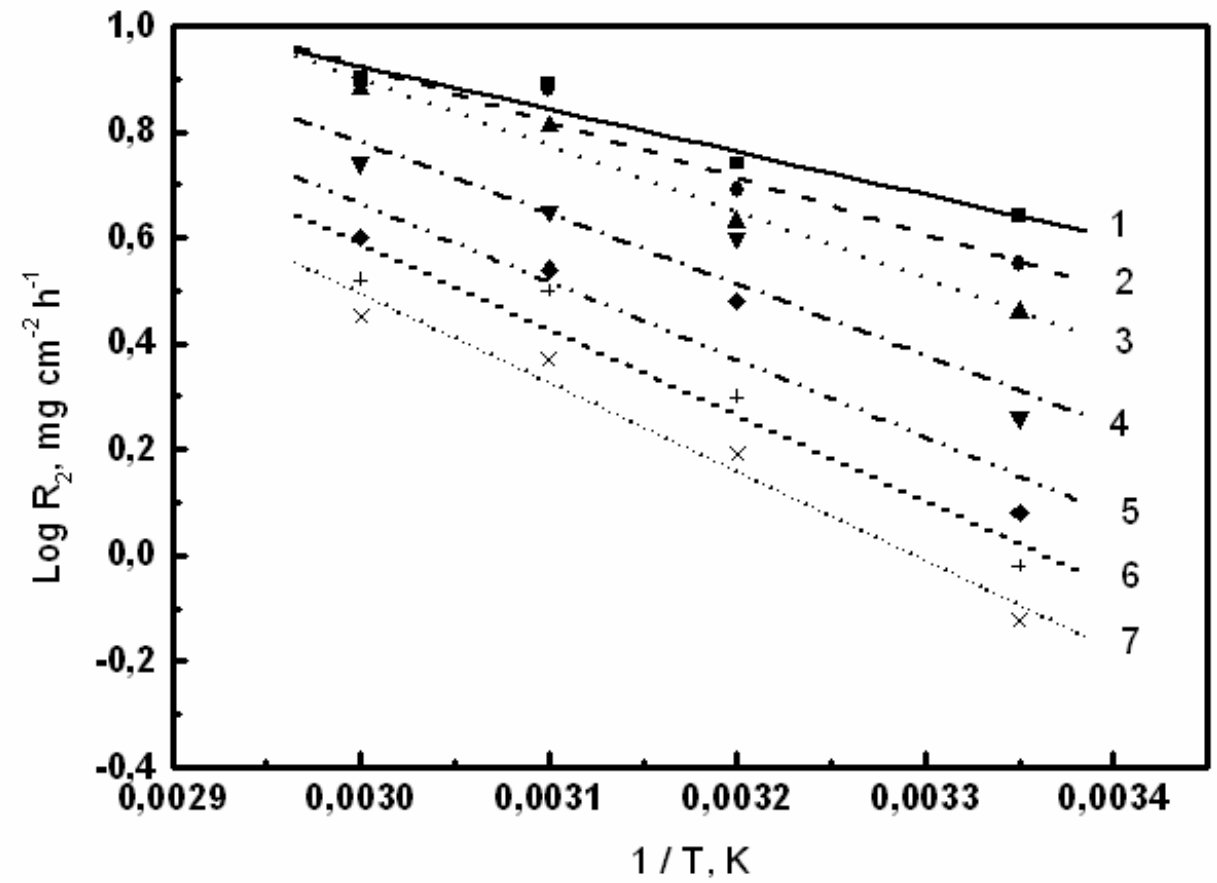

Figure 9. Arrhenius plot of the corrosion rate for 316L SS in $0.5 \mathrm{M} \mathrm{NaCl}$ in the presence of different concentrations of MBI: (1) 0.0 , (2) $10^{-6}$, (3) $10^{-5}$, (4) $10^{-4}$, (5) $3 \times 10^{-4}$, (6) $5 \times 10^{-4}$ and (7) $7 \times 10^{-4} \mathrm{M}$.

The high protective behavior of MBI can explain it by formation a barrier thick MBI film. The protective film formed by the initial adsorption processes of MBI, similar behavior obtained by Morales-Gil [20]. The IE decreases with the increasing of the temperature. The activation energy, enthalpy, and entropy changes $\left(\mathrm{E}_{\mathrm{a}}, \Delta \mathrm{H}\right.$ and $\left.\Delta \mathrm{S}\right)$ for the corrosion inhibition of $\mathrm{MBI}$ in $0.5 \mathrm{M} \mathrm{NaCl}$ calculated from the following: 
A- Arrhenius-type equation [21] (Table 1):

$$
\log \mathrm{R}_{2}=-\mathrm{E}_{\mathrm{a}} / 2.303 \mathrm{RT}+\mathrm{A}
$$

Symbol $\mathrm{R}_{2}$ is the corrosion rate in presence of $\mathrm{MBI}, \mathrm{E}_{\mathrm{a}}$ is the activation energy and $\mathrm{A}$ is the preexponential factor.

B- The transition-state equation [21]:

$$
\mathrm{R}_{2}=\mathrm{RT} / \mathrm{N}_{\mathrm{A}} \mathrm{h} \exp (\Delta \mathrm{S} / \mathrm{R}) \exp (-\Delta \mathrm{H} / \mathrm{RT})
$$

Where $\mathrm{h}$ is Planck's constant, $\mathrm{N}_{\mathrm{A}}$ is Avogadro's number, $\mathrm{R}$ the universal gas constant, $\Delta \mathrm{H}$ the enthalpy of the activation and $\Delta \mathrm{S}$ the entropy of activation.

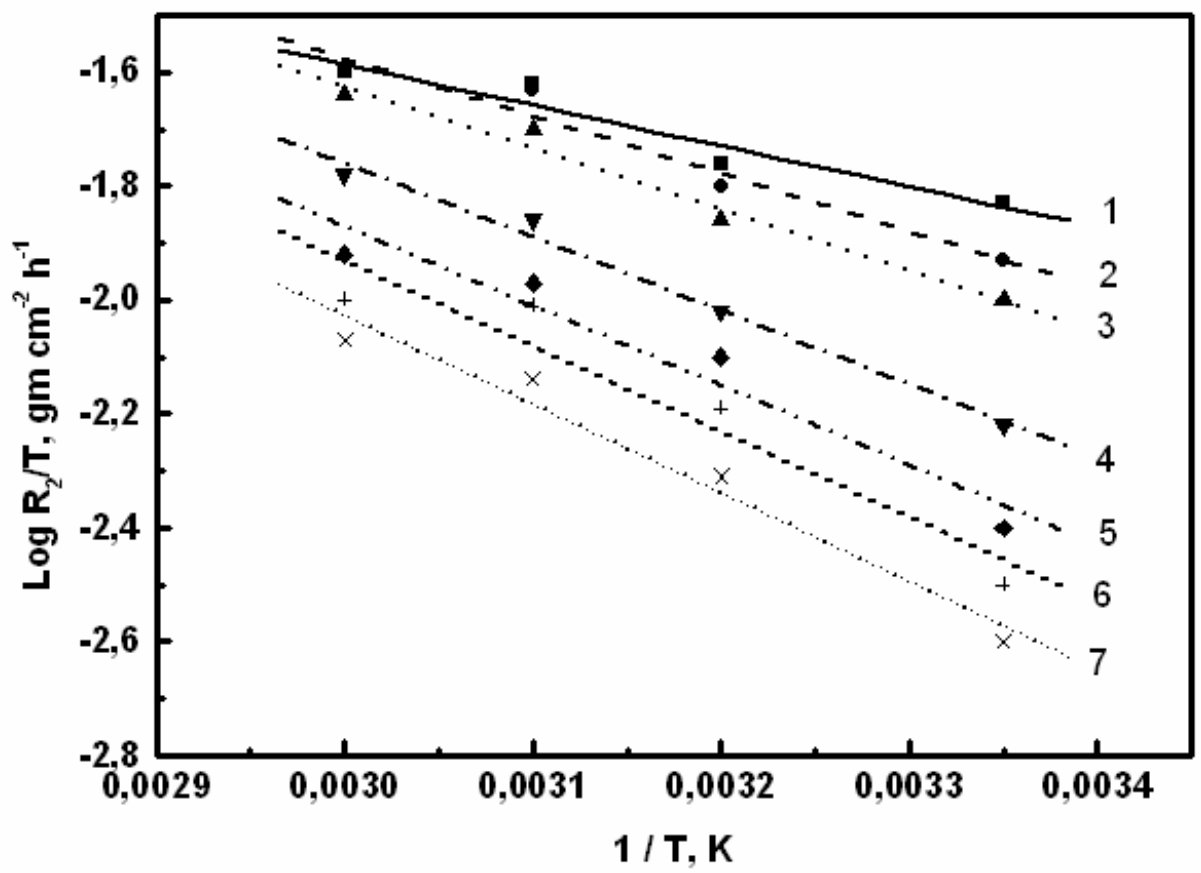

Figure 10. Transition state plot of the corrosion rate for the $316 \mathrm{~L} \mathrm{SS}$ in $0.5 \mathrm{M} \mathrm{NaCl}$ in the presence of different concentrations of MBI: (1) 0.0 , (2) $10^{-6}$, (3) $10^{-5}$, (4) $10^{-4}$, (5) $3 \times 10^{-4}$, (6) $5 \times 10^{-4}$ and (7) $7 \times 10^{-4} \mathrm{M}$.

A plot of $\log R_{2}$ versus $1 / T$ gave straight lines with slope $E_{a} / 2.303 R$ (as shown in Fig. 9). The $E_{a}$ for the corrosion reaction in absence and presence of MBI was calculated (Table 1). $\mathrm{E}_{\mathrm{a}}$ is depends on vthe MBI inhibitor concentration. The plots of $\log \mathrm{R}_{2} / \mathrm{T}$ against $1 / \mathrm{T}$ also gave straight lines, as shown in Fig (10). The slopes of these lines equal $-\Delta H / 2.303 R$ and the intercepts are $\log R T / N_{A} h+(\Delta S / 2.303 R)$, from which the values of $\Delta \mathrm{H}$ and $\Delta \mathrm{S}$ were calculated (Table 1). $\mathrm{E}_{\mathrm{a}}$ and $\Delta \mathrm{H}$ values in the presence of MBI inhibitor are different from those in free $0.5 \mathrm{M} \mathrm{NaCl}$ solution, i.e. no energy barrier attained [22]. 


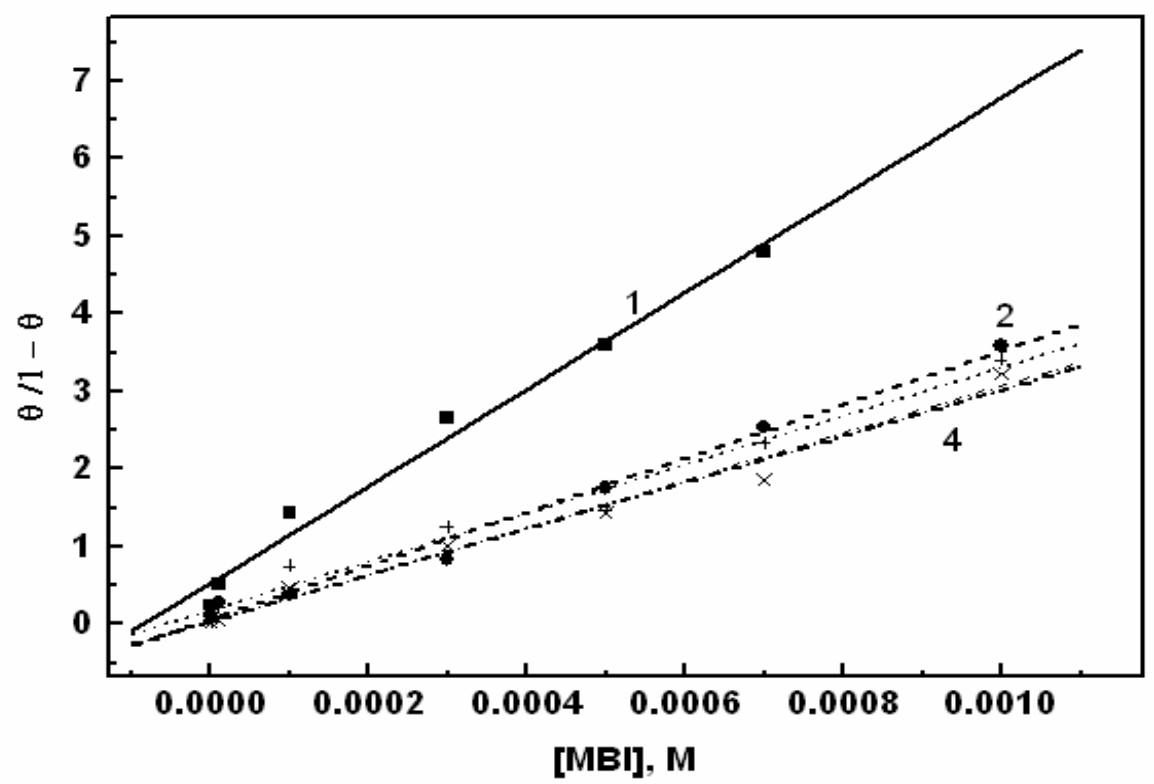

Figure 11. Curve fitting of the corrosion data for the $316 \mathrm{~L} \mathrm{SS}$ in $0.5 \mathrm{M} \mathrm{NaCl}$ in the presence of different concentrations of MBI to the Langmuir isotherm at different temperatures: (1) 25, (2) 40, (3) 50 and (4) $60^{\circ} \mathrm{C}$.

Table (2): Thermodynamic parameters for the adsorption of MBI in $0.5 \mathrm{M} \mathrm{NaCl}$ solution on 316L SS surface.

\begin{tabular}{|l|c|c|}
\hline $\begin{array}{c}\text { Temperature } \\
\left({ }^{\circ} \mathrm{C}\right)\end{array}$ & $\begin{array}{c}\mathrm{K} \\
\left(\mathrm{x} \mathrm{10} \mathrm{kJ} \mathrm{mol}^{-1}\right)\end{array}$ & $\begin{array}{c}-\Delta \mathrm{G} \\
\left(\mathrm{x} \mathrm{10} 0^{3} \mathrm{~kJ} \mathrm{~mol}^{-1}\right)\end{array}$ \\
\hline 25 & 10.92 & 32.93 \\
40 & 6.12 & 33.00 \\
50 & 4.17 & 33.12 \\
60 & 2.91 & 33.15 \\
\hline
\end{tabular}

The entropy of activation in the presence and absence of the inhibitors is large and negative. This implies that the activation complex in the rate-determining step represents association rather than dissociation, indicating that a decrease in disorder takes place on going from reactants to the activated complex. For MBI inhibitor, the experimental data fit a Langmuir adsorption isotherm, which given by [23]:

$$
\theta /(1-\theta)=\mathrm{KC}
$$

Symbol $\theta$ is the degree of the coverage $(\theta=\mathrm{IE} / 100), \mathrm{K}$ is the equilibrium constant of the adsorption process and $\mathrm{C}$ is the inhibitor concentration in the bulk of solution. The data gave straight lines with slopes of K. as shown in Figure 11. The free energy of adsorption $(\Delta \mathrm{G})$ calculated from the equation [24]: 


$$
\mathrm{K}=1 / 55.5 \exp (-\Delta \mathrm{G} / \mathrm{RT})
$$

The number 55.5 is the concentration of water in the solution in $\mathrm{M}$. The value of $\Delta \mathrm{G}$ and $\mathrm{K}$ are relatively small (Table 2), indicating electrostatic interaction between the double layer and the adsorbing molecules (physical adsorption). The equilibrium adsorption constants $\mathrm{K}$ follow the same trend in the sense that large values of $\mathrm{K}$ imply better more efficient adsorption and hence better inhibition efficiency.

\section{CONCLUSIONS}

The MBI compound has proven to be efficient inhibitor for general and pitting corrosion of 316L $\mathrm{SS}$ in $\mathrm{NaCl}$ solution. The inhibition efficiency of $\mathrm{MBI}$ inhibitor increases by increasing of the inhibitor concentration, but decreases with the increasing of temperature. The increase of MBI concentration increases the breakdown potential towards the positive direction, i.e. marked pitting corrosion inhibition. The corrosion inhibition behavior of MBI argued to the formation of MBI layer, which can impede the aggressive anions to reach to the base 316L SS surface throw the pits. The inhibition of 316L SS in $\mathrm{NaCl}$ solution at different temperatures found to obey the Langmuir adsorption isotherm. The kinetic parameters values obtained from this study $\left(\mathrm{E}_{\mathrm{a}}, \Delta \mathrm{H}\right.$ and $\left.\Delta \mathrm{S}\right)$ indicate that the presence of MBI inhibitor decrease the activation energies. The negative values of activation energies indicate the spontaneous adsorption of MBI on the surface of stainless steel.

\section{References}

1. M. G. Fontana and N. D. Greene, Corrosion Engineering, New York, McGraw-Hill, 1967, p. 51

2. M. E. Curley-Fiorino and G. M. Schmid, Corros. Sci., 20(1980)313

3. H. P. Leckie and H. H. Uhlig, J. Electrochem. Soc., 113, 1(1966)262

4. S. I. Ali and G. J. Abaschian, Corros. Sci., 18(1978) 15

5. H. C. Man and D. R. Gabe, Corros. Sci., 21(1981) 713

6. Z. Szklarska-Smialowska, Pitting Corrosion of Metals, Houston, TX:NACE, 359 (1986)

7. G. W. Poling, Corros. Sci., 26(1986) 27

8. M. Th. Makhhuf, S. A. El-Shatory and A. El-Said, Mater. Chem. Phys., 43, 1(1996)76

9. A. N. Starchak, A. N. Krasovskii, V. A. Anishchenko and L. D. Kosnkhina, Zashch. Met., 30, 4(1994) 405

10. G. L. Makovei, V. G. Ushakov, V. K. Bagin and V. P. Shemshei, Zashch. Met., 22, 3(1986) 47

11. S. Thibault and J. Talbot, Met. Corros-Ind., 50(1975) 51

12. L. Wang, Corros. Sci., 43, (2001) 2281

13. L. Wang, J. Pu and H. Luo, Corros. Sci. 45(2003) 677

14. S. A. M. Refaey, S. S. Abd El-Rehim, F. Taha, M. B. Saleh and R. A. Ahmed, Appl. Surf. Sci., 158(2000)190

15. S. Zhou, M. M. Stack and R. C. Newman, Corros. Sci., 38(1996) 1071

16. A. C. West, J. Electrochem. Soc., 140(1993) 403

17. J. D. Kim and S. I.. Pyun, Corros. Sci., 38(1996)1039

18. A. A. A. Boraei, I. T. Ahmed and M. M. A. Hamed, J Chem. Eng. Data, 41(1996) 787

19. A. G. Alshkel, M. M. Hefiny and A. R. Ismail, Corr. Prevent. Control, 155 (1976) 
20. P. Morales-Gil, G. Negrion-Silva, M. Romero-Romo, C. Angeles-Chavez and M. PalomarPardave, Electrochim. Acta, 49(2004)4733

21. I. Putilova, S. Balezin and V. Barannik, Metallic Corrosion Inhibitors, Oxford, UK, Pergamon Press, (1960).

22. K. Haladky, L. Collow and J. Dawson, Br. Corros. J., 15(1980)20

23. I. Langmuir, J. Am. Chem. Soc., 39(1947)1848

24. S. Arab and E. A. Noor, Corrosion, 49,2(1993)122

(C) 2006 by ESG (www.electrochemsci.org) 